\title{
Prognostic role of multidrug resistance-associated protein 1 expression and platelet count in operable non-small cell lung cancer
}

\author{
LINMING FANG $^{1 *}$, HUAYING SHENG $^{1 *}$, DANYING WAN $^{1}$, CHIHONG ZHU $^{1}$, RUIBIN JIANG ${ }^{1}$, \\ XIAOJIANG SUN ${ }^{1,2}$ and JIANGUO FENG ${ }^{1,2}$ \\ ${ }^{1}$ Cancer Research Institute, Zhejiang Cancer Hospital; ${ }^{2}$ Key Laboratory Diagnosis and Treatment Technology \\ on Thoracic Oncology, Hangzhou, Zhejiang 310022, P.R. China
}

Received October 18, 2017; Accepted March 28, 2018

DOI: $10.3892 / \mathrm{ol} .2018 .8763$

\begin{abstract}
The overall survival rate of patients with non-small cell lung cancer (NSCLC) following resection remains poor due to the high rates of recurrence and metastasis. The investigation of novel biomarkers is clinically necessary to improve treatment strategies. Multidrug resistance-associated protein 1 (MRP1) and platelet count are linked to a poor prognosis in various types of cancer. However, it is unknown whether MRP1 or platelet count is a suitable prognostic indicator of NSCLC. In the present study, 427 patients with operable NSCLC were enlisted. The association of MRP1 expression and platelet count with clinical pathological factors and patient outcome was evaluated. MRP1 expression was found to be significantly associated with sex, histological type and tumor differentiation, while platelet count was significantly associated with smoking behavior, histological type and clinical stage. Platelet count was significantly higher in patients with negative MRP1 expression than in those with positive MRP1 expression. Survival analysis indicated that there was no association between MRP1 expression and disease-free survival (DFS) or overall survival (OS) time. In the patients with no lymph node metastasis, the OS time was significantly longer in patients with positive MRP1 expression than in those with negative expression. However, in the patients with lymph node metastasis, the DFS time was significantly shorter in patients with positive MRP1 expression than in those with negative expression. There was an association between the platelet count and DFS and
\end{abstract}

Correspondence to: Dr Jianguo Feng, Cancer Research Institute, Zhejiang Cancer Hospital, 1 Banshan Dong Road, Hangzhou, Zhejiang 310022, P.R. China

E-mail: fengjg@zjcc.org.cn

${ }^{*}$ Contributed equally

Key words: multidrug resistance-associated protein 1, platelet, non-small cell lung cancer, survival
OS times, which were significantly longer in patients with a normal platelet count than in those with thrombocytosis. In conclusion, MRP1 expression and platelet count are valuable independent prognostic biomarkers for survival in operable NSCLC.

\section{Introduction}

Lung cancer is one of the most common malignancies globally, with non-small cell lung cancer (NSCLC) accounting for the main type, exhibiting a high mortality rate and poor prognosis (1). The management techniques for NSCLC include surgery, radiotherapy and chemotherapy; however, they exhibit limited effectiveness for NSCLC. Radical surgery has been the standard treatment for early-stage NSCLC. However, patients with similar stages and histological classifications have markedly different survival outcomes (2). The following resection remains poor due to the high rate of recurrence and metastasis. The prognosis of NSCLC is predominantly based on the Tumor-Node-Metastasis (TNM) staging system, but TNM staging is not able to accurately predict clinical prognosis $(3,4)$. Numerous promising biomarkers have been evaluated as potential prognosis predictors of NSCLC; however, none of them have been proven effective for clinical use. Therefore, investigation of novel biomarkers is clinically necessary to improve treatment strategies.

Multidrug resistance (MDR)-associated protein 1 (MRP1) is a member of the ATP-binding cassette membrane transporter family of proteins. MRP1 is primarily expressed in the basolateral membrane of epithelial cells, and governs the absorption and disposition of a wide variety of endogenous and exogenous substrates $(5,6)$. MRP1 is implicated in MDR and accommodates the efflux of conventional cytotoxic anticancer agents (7). Overexpression of MRP1 has been associated with drug resistance and poor outcome in lung, breast and gastric cancer cells and patients (8-13).

Platelets serve a multifaceted role in blood clotting, inflammatory response, fibrinolysis and neoplasia. Interactions between tumor cells and platelets are associated with tumor aberrant angiogenesis, invasion and metastasis $(14,15)$. 
Previous studies have demonstrated that increased platelet count is linked to a poor prognosis in various types of cancer, including gastric, pancreatic, ovarian, colorectal and breast cancer (16-20).

However, due to variance in study design and sample size, these studies have reported inconsistent results. It is therefore unknown whether MRP1 or platelet count is a suitable prognostic indicator of NSCLC. In the present study, a retrospective clinical analysis was designed to investigate the prognostic impact of MRP1 and platelet count on the patients' characteristics and survival in those with operable NSCLC.

\section{Materials and methods}

Patients and treatment. Between June 2007 and June 2011, 427 patients with operable NSCLC were enrolled in the present study at Zhejiang Cancer Hospital (Hangzhou, Zhejiang, China). Patients were newly diagnosed and histologically confirmed, without any preoperative anticancer therapy. The histological diagnosis was based on the classification criteria for lung tumors of the World Health Organization and International Association for the Study of Lung Cancer (WHO/IASLC) (21). The tumor stage was defined according to the seventh edition of the TNM classification (4). The protocol of present study was approved by the Institutional Review Board of Zhejiang Cancer Hospital. All patients provided written informed consent prior to surgery.

Blood samples $(3 \mathrm{ml})$ were obtained from each patient prior to surgery. Platelet count was measured using the XE2100 automatic hematology analyzer (Sysmex Co., Tokyo, Japan). A platelet count of $<300 \times 10^{9} / 1$ was regarded as normal, while a count of $>300 \times 10^{9} / 1$ was defined as thrombocytosis, according to the manufacturer's protocols.

All patients underwent radical resection of pulmonary carcinoma and radical mediastinal lymph node dissection. All patients received standardized follow-up at a 3-month interval until October 30, 2016. Among the 427 patients, 225 relapsed during the follow-up, with 200 mortalities, while 15 patients had no record of distal metastasis and 19 patients had no record of overall survival.

Tissue microarray (TMA). TMA blocks were obtained from 427 patients with $1.0-\mathrm{mm}$ diameter representative regions used for each case. Hematoxylin and eosin (H\&E) slides (5-mm) were used to identify and mark out representative areas of tumor tissue. The cores were carefully selected from H\&E stained sections and inserted into new paraffin blocks using Tissue Arrayer Minicore (Alphelys, Plaisir, France).

Immunohistochemistry (IHC). Samples were fixed in $4 \%$ paraformaldehyde solution at $4^{\circ} \mathrm{C}$ for $24 \mathrm{~h}$, embedded in paraffin and cut into $15-\mu \mathrm{m}$ serial sections. Routine hematoxylin and eosin staining was performed (hematoxylin staining for $5 \mathrm{~min}$ and eosin staining for $2 \mathrm{~min}$, both at room temperature). Then the sections were deparaffinized with xylene, and washed using 100, 90 and $70 \%$ ethanol, then distilled water. The sections (15 $\mu \mathrm{m}$ thick) were primed for antigen retrieval in citrate buffer $(\mathrm{pH} 6.0)$ using microwave heating for a 5-min cycle. Sections were incubated with primary antibody against MRP1 (dilution, 1:200; cat. no. 72202; Cell Signaling Technology, Inc., Danvers, MA, USA) overnight at $4^{\circ} \mathrm{C}$, followed by incubation with biotin labeled goat anti-mouse $\mathrm{IgG}$ and horseradish peroxidase-conjugated streptavidin secondary antibody (dilution, 1:500; Santa Cruz Biotechnology, Inc., Dallas, TX, USA) for $1 \mathrm{~h}$ at room temperature, stained with $5 \mathrm{mg} / \mathrm{ml}$ DAB (Dako Cytomation; cat no. GK346810; Dako; Agilent Technologies, Inc., Sana Clara, CA, USA) for $10 \mathrm{~min}$ at room temperature and counterstained with hematoxylin for $2 \mathrm{~min}$ at room temperature according to the manufacturer's protocol. The slides were scored according to staining intensity as follows: 0 , negative $(-)$; 1 , weak positive $(+) ; 2$, positive $(++)$, and 3 , strong positive $(+++)$. The percentage of positive cells were scored from $0-3$ as follows: $0,<5 \%$; $1,5-25 \%$; $2,25-50 \%$, and $3,>50 \%$. The final IHC score was a result of multiplying the two scores, with a score of 0 indicating a negative expression and a score of 1-3 indicating a positive expression.

Statistical analysis. A one-way analysis of variance and $\chi^{2}$ test were performed to evaluate the association between the clinicopathological variables and MRP1 expression. DFS and OS were analyzed by Kaplan-Meier curves and log-rank test. All the statistical calculations were performed using SPSS 15.0 (SPSS, Inc., Chicago, IL, USA). P<0.05 was considered to indicate a statistically significant difference.

\section{Results}

Characteristics of patients. Among the 427 patients, there were 333 men and 94 women (age range, 38-78 years; mean, $59.7 \pm 8.8$ years). According to the WHO/IASLC classification criteria for lung tumors, there were 197 cases of adenocarcinoma and 230 cases of squamous cell carcinoma. According to the IASLC staging system, there were 163 cases of stage I (25 cases of stage Ia and 138 cases of stage Ib), 120 cases of stage II ( 2 cases of stage IIa and 118 cases of stage IIb) and 143 cases of stage III (116 cases of stage IIIa and 27 cases of stage IIIb). Only 1 case had no staging information.

Association between MRPI expression and patient characteristics. The expression of MRP1 protein was localized in the cytoplasm (Fig. 1). Among the 427 patients, there were $208(48.7 \%)$ patients with positive or strong-positive MRP1 expression and $219(51.3 \%)$ patients with weak-positive or negative MRP1 expression. MRP1 expression was significantly associated with histological type and tumor differentiation, and there was a statistically significant difference between the expression of MRP and the count of PTL (Table I). However, sex, stage, lymph node metastasis, family history, smoking and alcohol intake history did not have significant association with MRP1 expression (Tables I and II).

Association between platelet count and patient characteristics. The platelet count in all 427 patients range from 67 to $704 \times 10^{9} / 1$. A total of 375 patients $(87.8 \%)$ had a normal platelet count $\left(<300 \times 10^{9} / 1\right)$ and $62(14.5 \%)$ had thrombocytosis $\left(>300 \times 10^{9} / 1\right)$. The number of platelets was analyzed using a T-test, and 
Table I. Multidrug resistance-associated protein 1 protein expression with multivariate analysis of prognosis in patients with non-small cell lung cancer.

\begin{tabular}{|c|c|c|c|c|c|c|c|}
\hline \multirow[b]{2}{*}{ Factors } & \multirow[b]{2}{*}{ B } & \multirow[b]{2}{*}{ Standard error } & \multirow[b]{2}{*}{ Wald } & \multirow[b]{2}{*}{ P-value } & \multirow[b]{2}{*}{$\operatorname{Exp}(B)$} & \multicolumn{2}{|c|}{$\begin{array}{c}\text { Exp (B) of } \\
95 \% \text { confidence interval }\end{array}$} \\
\hline & & & & & & Lower limit & Upper limit \\
\hline Sex & & & & & & & \\
\hline $\begin{array}{l}\text { Male } \\
\text { Female }\end{array}$ & 0.595 & 0.435 & 1.869 & 0.172 & 1.813 & 0.773 & 4.253 \\
\hline $\begin{array}{l}\text { Age, years } \\
<65 \\
\geq 65\end{array}$ & -0.096 & 0.224 & 0.185 & 0.667 & 0.908 & 0.585 & 1.409 \\
\hline $\begin{array}{l}\text { Family history } \\
\text { No } \\
\text { Yes }\end{array}$ & 0.108 & 0.263 & 0.167 & 0.683 & 1.114 & 0.665 & 1.864 \\
\hline $\begin{array}{l}\text { Smoking } \\
\text { Never } \\
\text { Ever/current }\end{array}$ & 0.381 & 0.404 & 0.887 & 0.346 & 1.463 & 0.663 & 3.230 \\
\hline $\begin{array}{l}\text { Alcohol } \\
\text { Never } \\
\text { Ever/current }\end{array}$ & 0.302 & 1.455 & 0.043 & 0.836 & 1.353 & 0.078 & 23.408 \\
\hline $\begin{array}{l}\text { Histological type } \\
\text { Squamous cell carcinoma } \\
\text { Adenocarcinoma }\end{array}$ & 0.905 & 0.241 & 14.100 & $<0.001^{\mathrm{a}}$ & 2.472 & 1.541 & 3.964 \\
\hline $\begin{array}{l}\text { Grade } \\
\text { High-middle } \\
\text { Middle-low }\end{array}$ & -0.734 & 0.219 & 11.182 & $0.001^{\mathrm{a}}$ & 0.480 & 0.312 & 0.738 \\
\hline $\begin{array}{l}\text { Clinical stage } \\
\text { I-II } \\
\text { III }\end{array}$ & 0.058 & 0.219 & 0.040 & 0.791 & 1.060 & 0.690 & 1.626 \\
\hline $\begin{array}{l}\text { Lymph node metastasis } \\
\text { No } \\
\text { Yes }\end{array}$ & 0.238 & 0.254 & 0.877 & 0.349 & 1.268 & 0.771 & 2.085 \\
\hline $\begin{array}{l}\text { PLT } \\
\quad<300 \times 10^{9} / 1 \\
\geq 300 \times 10^{9} / 1\end{array}$ & 0.852 & 0.252 & 9.854 & 0.001 & 1.985 & 1.456 & 2.989 \\
\hline
\end{tabular}

${ }^{\mathrm{a}} \mathrm{P}<0.05$. PLT, platelet.

patients with platelet numbers higher compared with the normal value were grouped into the high group, and those with lower platelet numbers compared with the normal value were grouped into the low group. A $\chi^{2}$ test was performed with pathological data. Platelet count was significantly associated with smoking behavior $(\mathrm{P}=0.041)$, histological type $(\mathrm{P}=0.039)$, clinical stage $(\mathrm{P}=0.007)$ and lymph node metastasis $(\mathrm{P}=0.003)$ (Table III). Platelet count was significantly higher in patients of stage III compared with those of stage I-II $(\mathrm{P}=0.021)$, in patients with lymph node metastasis than in those with no lymph node metastasis $(\mathrm{P}=0.014)$ and in smokers than in non-smokers $(\mathrm{P}=0.017)$. Other factors, including age, sex, family history, alcohol intake history and tumor differentiation, did not have a significant association with platelet count (Table IV). Furthermore, platelet count was significantly higher in patients with negative MRP1 expression than in those with positive MRP1 expression (Fig. 2).

Association of MRPl expression with survival. There was no association between MRP1expression and OS $(\mathrm{P}=0.441)$ or DFS $(\mathrm{P}=0.656)$ according to Kaplan-Meier analysis and log-rank test (Fig. 3A and D). However, in the patients with no lymph node metastasis, the OS time was significantly longer in patients with positive MRP1 expression than in those with negative expression ( $\mathrm{P}=0.009$ ) (Fig. 3B). Notably, in the patients with lymph node metastasis, the DFS time was significantly shorter in patients with positive MRP1 expression than in those with negative expression $(\mathrm{P}=0.022)$ (Fig. 3F) (Table V). 
Table II. Association of MRP1 protein expression with clinicopathological factors in patients with non-small cell lung cancer.

\begin{tabular}{|c|c|c|c|c|}
\hline \multirow[b]{2}{*}{ Factors } & \multirow[b]{2}{*}{ Patients, n (\%) } & \multicolumn{2}{|c|}{ MRP1 expression } & \multirow[b]{2}{*}{ P-value } \\
\hline & & Negative, n (\%) & Positive, n (\%) & \\
\hline Sex & & & & 0.017 \\
\hline Male & $333(78.0)$ & $181(42.4)$ & $152(35.6)$ & \\
\hline Female & $94(22.0)$ & $38(8.9)$ & $56(13.1)$ & \\
\hline Age, years & & & & 0.704 \\
\hline$<65$ & $296(69.3)$ & $150(35.1)$ & $146(34.2)$ & \\
\hline$\geq 65$ & $131(30.7)$ & $69(16.2)$ & $62(14.5)$ & \\
\hline Family history & & & & 0.375 \\
\hline No & $328(76.8)$ & $176(41.2)$ & $152(35.6)$ & \\
\hline Yes & 77 (18.0) & $37(8.7)$ & $40(9.4)$ & \\
\hline Smoking & & & & 0.086 \\
\hline Never & $114(26.7)$ & $52(12.2)$ & $62(14.5)$ & \\
\hline Ever/current & 293 (68.6) & $162(37.9)$ & $131(30.7)$ & \\
\hline Alcohol & & & & 0.655 \\
\hline Never & $197(46.1)$ & $99(23.2)$ & $98(23.0)$ & \\
\hline Ever/current & 208 (48.7) & $114(26.7)$ & $94(22.0)$ & \\
\hline Histological type & & & & $<0.001^{\mathrm{a}}$ \\
\hline Squamous cell carcinoma & $230(53.9)$ & $136(31.9)$ & $94(22.0)$ & \\
\hline Adenocarcinoma & $197(46.1)$ & $83(19.4)$ & $114(26.7)$ & \\
\hline Grade & & & & $0.014^{\mathrm{a}}$ \\
\hline High-middle & $210(49.2)$ & $95(22.2)$ & $115(26.9)$ & \\
\hline Middle-low & $217(50.8)$ & $124(29.0)$ & $93(21.8)$ & \\
\hline Clinical stage & & & & 0.866 \\
\hline I-II & $283(66.3)$ & $114(26.7)$ & 139 (32.6) & \\
\hline III & $143(33.5)$ & $74(17.3)$ & $69(16.2)$ & \\
\hline Lymph node metastasis & & & & 0.664 \\
\hline No & $193(45.2)$ & $101(23.7)$ & $92(21.5)$ & \\
\hline Yes & $231(54.1)$ & $116(27.2)$ & $115(26.9)$ & \\
\hline
\end{tabular}

${ }^{\mathrm{a}}<0.05$. MRP1, multidrug resistance-associated protein 1 .

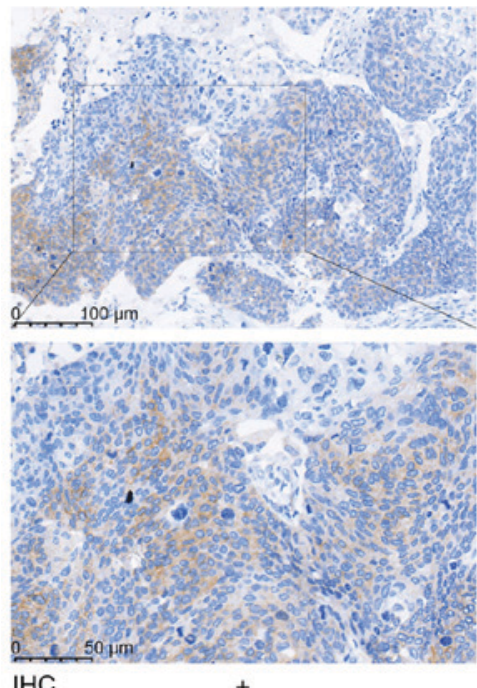

$\mathrm{IHC}$

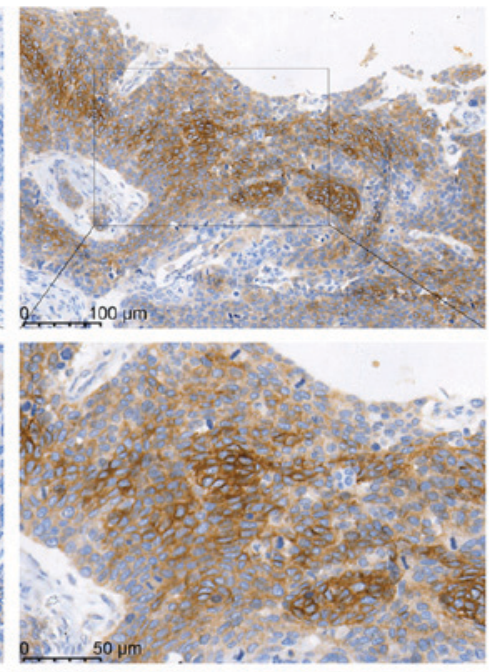

$++$

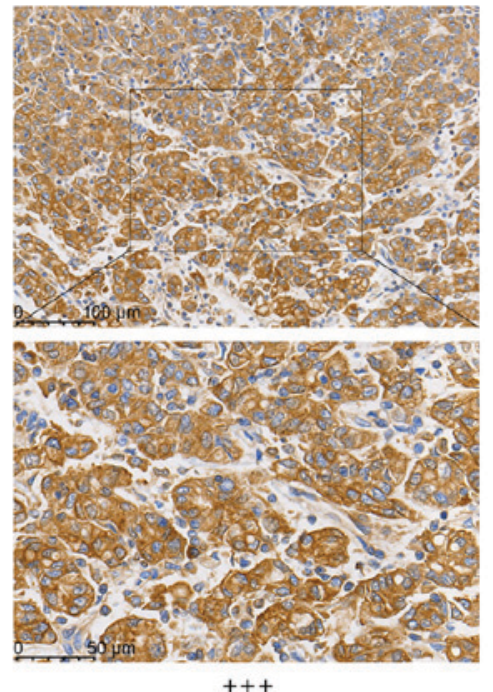

$+++$

Figure 1. Expression of MRP1 protein was localized in the cytoplasm (top panels: magnification, x200; scale bars, $100 \mu \mathrm{m}$; bottom panels: magnification, $\mathrm{x} 400$; scale bars, $50 \mu \mathrm{m}$ ). IHC, immunohistochemistry; MRP1, multidrug resistance-associated protein 1. 
Table III. Association of PLT level with clinicopathological factors in patients with non-small cell lung cancer.

\begin{tabular}{|c|c|c|c|c|c|c|}
\hline \multirow[b]{2}{*}{ Factors } & \multirow[b]{2}{*}{$\begin{array}{l}\text { Patients, } \\
\mathrm{n}(\%)\end{array}$} & \multirow{2}{*}{$\begin{array}{c}\text { PLT }\left(\times 10^{9} / 1\right) \\
\text { Median } \\
(\text { mean, 5-95th })\end{array}$} & \multirow[b]{2}{*}{ P-value } & \multicolumn{2}{|c|}{ PLT } & \multirow[b]{2}{*}{ P-value } \\
\hline & & & & $\begin{array}{c}\text { Low expression, } \\
\mathrm{n}(\%)\end{array}$ & $\begin{array}{c}\text { High expression, } \\
\mathrm{n}(\%)\end{array}$ & \\
\hline Sex & & & 0.095 & & & $0.028^{\mathrm{a}}$ \\
\hline Male & $333(78.0)$ & $214.0(226.4,217.2-235.5)$ & & $278(65.1)$ & $55(12.9)$ & \\
\hline Female & $94(22.0)$ & $200.0(210.6,197.4-223.7)$ & & $87(20.4)$ & $7(1.6)$ & \\
\hline Age, years & & & 0.575 & & & 0.135 \\
\hline$<65$ & $296(69.3)$ & $213.0(224.3,215.2-233.5)$ & & $248(58.1)$ & $48(11.2)$ & \\
\hline$\geq 65$ & $131(30.7)$ & $202.0(219.6,205.1-234.0)$ & & $117(27.4)$ & $14(3.3)$ & \\
\hline Family history & & & 0.169 & & & 0.426 \\
\hline No & $328(76.8)$ & $215.0(225.1,216.5-233.6)$ & & $128(30.0)$ & $50(11.7)$ & \\
\hline Yes & $77(18.0)$ & $185.0(213.7,193.1-234.2)$ & & $68(15.9)$ & $9(2.1)$ & \\
\hline Smoking & & & 0.447 & & & $0.041^{\mathrm{a}}$ \\
\hline Never & $114(26.7)$ & $202.5(213.8,201.6-226.0$ & & $104(24.4)$ & $10(2.3)$ & \\
\hline Ever/current & $293(68.6)$ & $213.0(226.1,216.2-236.0)$ & & $244(57.1)$ & 49 (11.5) & \\
\hline Alcohol & & & 0.805 & & & 0.840 \\
\hline Never & $197(46.1)$ & $208.0(223.8,212.4-235.1)$ & & $168(39.3)$ & $29(6.8)$ & \\
\hline Ever/current & $208(48.7)$ & $210.0(221.8,210.6-233.0)$ & & $178(41.7)$ & $30(7.0)$ & \\
\hline Histological type & & & $0.039^{\mathrm{a}}$ & & & 0.473 \\
\hline Squamous cell carcinoma & $230(53.9)$ & $222.0(229.5,218.7-240.2)$ & & $194(45.4)$ & $36(8.4)$ & \\
\hline Adenocarcinoma & $197(46.1)$ & $199.0(215.2,204.2-226.2)$ & & $171(40.0)$ & $26(6.1)$ & \\
\hline Grade & & & 0.971 & & & 0.491 \\
\hline High-middle & $210(49.2)$ & $222.0(229.5,218.7-240.2)$ & & $177(41.5)$ & $33(7.7)$ & \\
\hline Middle-low & $217(50.8)$ & $199.0(215.2,204.2-226.2)$ & & $188(44.0)$ & $29(6.8)$ & \\
\hline Clinical stage & & & $0.007^{\mathrm{a}}$ & & & $0.003^{\mathrm{a}}$ \\
\hline I-II & $283(66.3)$ & $206.0(215.5,206.7-224.3)$ & & $252(59.0)$ & $31(7.3)$ & \\
\hline III & $143(33.5)$ & $226.0(237.8,223.0-252.6)$ & & $112(26.2)$ & $31(7.3)$ & \\
\hline Lymph node metastasis & & & 0.030 & & & $0.046^{\mathrm{a}}$ \\
\hline No & $193(45.2)$ & $201.0(213.9,203.7-224.1)$ & & $172(40.3)$ & $21(4.9)$ & \\
\hline Yes & $231(54.1)$ & $221.0(231.0,219.7-242.3)$ & & $190(44.5)$ & $41(9.6)$ & \\
\hline MRP1 & & & $0.014^{\mathrm{a}}$ & & & $0.002^{\mathrm{a}}$ \\
\hline Negative (-/+) & $219(51.3)$ & $221.0(232.3,221.2-243.5)$ & & $176(41.2)$ & $43(10.1)$ & \\
\hline Positive $(++/+++)$ & $208(48.7)$ & $206.5(213.0,202.4-223.6)$ & & $189(44.3)$ & $19(4.4)$ & \\
\hline
\end{tabular}

${ }^{a} \mathrm{P}<0.05$. PLT, platelet. Some data does not add up to 427 patients as the data of pathological factors were insufficient, and the pathological factors in each group were obtained from cases where a statistically significant difference was identified.

Association of platelet count with survival. There was an association between the platelet count and OS $(\mathrm{P}=0.008)$ or DFS $(\mathrm{P}=0.025)$ according to Kaplan-Meier analysis and log-rank test (Fig. 4A and D). The DFS and OS times were significantly longer in patients with a normal platelet count $\left(<300 \times 10^{9} / 1\right)$ than in those with thrombocytosis $\left(>300 \times 10^{9} / 1\right)$. There was no association between the platelet count and survival for the presence and absence of lymph node metastasis (Fig. 4B, C, E and F).

\section{Discussion}

MRP1 has previously been evaluated and is known to serve an important role in MDR in vitro (22-24). MRP1 has also been associated with a poor outcome in NSCLC patients $(25,26)$.
Preclinical studies showed that MRP1 protein levels correlated with the resistance to chemotherapeutic agents in NSCLC cell lines, including SK-MES-1, A549, Calu-1, Calu-6, SW-900, SK-LU-1, SK-Luci-6, and SW-1573 $(23,24)$. Although high levels of MRP1 expression are frequently observed in the specimens of NSCLC patients, the predictive value of MRP1 expression remains a controversial issue (25-29). Certain previous studies reported that patients with NSCLC with high MRP1 expression had a poorer prognosis than those with low MRP1 expression $(25,27)$. However, another study indicated that high MRP1 expression contributed to longer OS times in NSCLC patients (27). It was also reported that there was no association between MRP1 expression and survival in advanced-stage NSCLC patients 
Table IV. Platelet level with multivariate analysis of prognosis in patients with non-small cell lung cancer.

\begin{tabular}{|c|c|c|c|c|c|c|c|}
\hline \multirow[b]{2}{*}{ Factors } & \multirow[b]{2}{*}{ B } & \multirow[b]{2}{*}{ Standard error } & \multirow[b]{2}{*}{ Wald } & \multirow[b]{2}{*}{ P-value } & \multirow[b]{2}{*}{$\operatorname{Exp}(B)$} & \multicolumn{2}{|c|}{$\begin{array}{c}\text { Exp (B) of } \\
95 \% \text { confidence interval }\end{array}$} \\
\hline & & & & & & Lower limit & Upper limit \\
\hline Sex & & & & & & & \\
\hline $\begin{array}{l}\text { Male } \\
\text { Female }\end{array}$ & -0.311 & 0.434 & 0.514 & 0.473 & 0.732 & 0.313 & 1.715 \\
\hline $\begin{array}{l}\text { Age, years } \\
<65 \\
\geq 65\end{array}$ & -0.363 & 0.224 & 2.619 & 0.106 & 0.695 & 0.448 & 1.080 \\
\hline $\begin{array}{l}\text { Family history } \\
\text { No } \\
\text { Yes }\end{array}$ & 0.105 & 0.398 & 0.070 & 0.791 & 1.111 & 0.509 & 2.425 \\
\hline $\begin{array}{l}\text { Smokings } \\
\text { Never } \\
\text { Ever/current }\end{array}$ & -0.641 & 0.269 & 5.663 & $0.017^{\mathrm{a}}$ & 0.527 & 0.311 & 0.893 \\
\hline $\begin{array}{l}\text { Alcohol } \\
\text { Never } \\
\text { Ever/current }\end{array}$ & -0.418 & 0.310 & 1.816 & 0.178 & 0.659 & 0.545 & 1.209 \\
\hline $\begin{array}{l}\text { Histological type } \\
\text { Squamous cell carcinoma } \\
\text { Adenocarcinoma }\end{array}$ & -0.581 & 0.241 & 5.791 & $0.016^{\mathrm{a}}$ & 0.560 & 0.349 & 0.898 \\
\hline $\begin{array}{l}\text { Grade } \\
\text { High-middle } \\
\text { Middle-low }\end{array}$ & 0.216 & 0.217 & 0.983 & 0.321 & 1.241 & 0.810 & 1.900 \\
\hline $\begin{array}{l}\text { Clinical stage } \\
\text { I-II } \\
\text { III }\end{array}$ & 0.508 & 0.220 & 5.324 & $0.021^{\mathrm{a}}$ & 1.661 & 1.079 & 2.557 \\
\hline $\begin{array}{l}\text { Lymph node metastasis } \\
\text { No } \\
\text { Yes }\end{array}$ & 0.599 & 0.243 & 6.060 & 0.014 & 0.550 & 0.341 & 0.855 \\
\hline $\begin{array}{l}\text { MRP1 } \\
\text { Negative }(-/+) \\
\text { Positive }(++/+++)\end{array}$ & -0.590 & 0.213 & 5.794 & $0.001^{\mathrm{a}}$ & 0.526 & 1.245 & 2.255 \\
\hline
\end{tabular}

${ }^{\mathrm{a}} \mathrm{P}<0.05$. MRP1, multidrug resistance-associated protein 1.

following platinum-based chemotherapy (28), and another study confirmed that no significant association between MRP1 expression and OS time was observed in completely resected NSCLC patients (29). In the present study, it was found that MRP1 expression was significantly associated with sex, histological type and tumor differentiation. There was no association between MRP1 expression and DFS. However, in the patients with no lymph node metastasis, the OS time was significantly longer in patients with positive MRP1 expression than in those with negative expression $(\mathrm{P}=0.009)$. Notably, in the patients with lymph node metastasis, the DFS time was significantly shorter in patients with positive MRP1 expression than in those with negative expression. The differences between the present study and previous studies may be due to different experimental detective

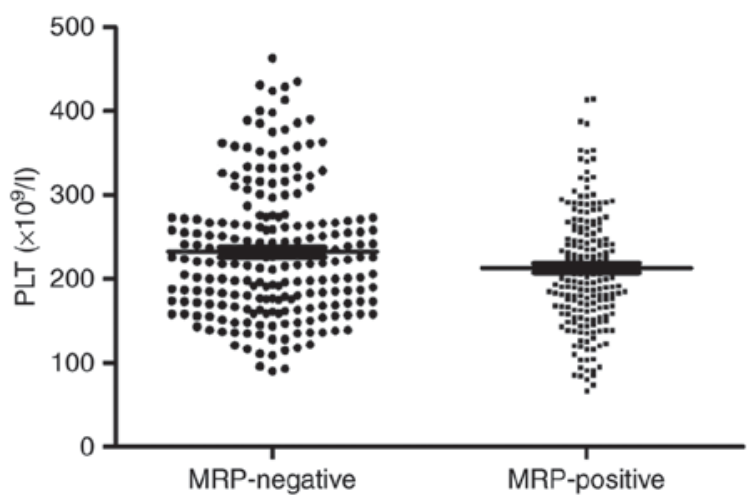

Figure 2. Platelet count was significantly higher in patients with negative MRP1 expression than in those with positive MRP1 expression $(\mathrm{P}=0.014)$. PLT, platelet; MRP1, multidrug resistance-associated protein 1. 
Table V. Association between the expression of MRP1 protein and the prognosis of patients with lymph node metastasis.

A, No lymph node metastasis

\begin{tabular}{|c|c|c|c|c|c|c|}
\hline Factor & Crude HR & $95 \% \mathrm{CI}$ & P-value & Adjusted HR & $95 \% \mathrm{CI}$ & P-value \\
\hline \multicolumn{7}{|c|}{ Disease-free survival } \\
\hline MRP1-negative & 1.000 & & & 1.000 & & \\
\hline MRP1-positive & 1.453 & $0.960-2.199$ & 0.077 & 0.726 & $0.443-1.190$ & 0.204 \\
\hline \multicolumn{7}{|l|}{ Overall survival } \\
\hline MRP1-negative & 1.000 & & & 1.000 & & \\
\hline MRP1-positive & 0.521 & $0.317-0.857$ & $0.010^{\mathrm{e}}$ & 0.554 & $0.333-0.923$ & 0.023 \\
\hline
\end{tabular}

B, Lymph node metastasis

\begin{tabular}{|c|c|c|c|c|c|c|}
\hline Factor & Crude HR & $95 \% \mathrm{CI}$ & P-value & Adjusted HR & $95 \%$ CI & P-value \\
\hline \multicolumn{7}{|c|}{ Disease-free survival } \\
\hline MRP1-negative & 1.000 & & & 1.000 & & \\
\hline MRP1-positive & 0.710 & $0.439-1.147$ & 0.162 & 1.400 & $0.921-2.127$ & 0.115 \\
\hline \multicolumn{7}{|l|}{ Overall survival } \\
\hline MRP1-negative & 1.000 & & & 1.000 & & \\
\hline MRP1-positive & 1.277 & $0.870-1.731$ & 0.244 & 1.223 & $0.862-1.733$ & 0.259 \\
\hline
\end{tabular}

Associations determined by Cox proportional hazards regression and adjusted for sex, grade and histotype. 95\% Wald confidence limits. HR for relapse with respect to MRP1-positive concentration HR for mortality with respect to MRP1-positive concentration. $\mathrm{P}<0.05$. HR, hazard ratio; CI, confidence interval; MRP1, multidrug resistance-associated protein 1.

methodologies and sample types. The present results suggest that MRP1 is a predictive factor for the survival of NSCLC patients.

Platelets serve a critical role in tumor progression and metastasis. Studies have confirmed the association between platelets and tumor biology. Platelets act as an important regulator in physiological processes; however, angiogenesis is associated with tumor growth and metastasis $(14,30,31)$. Platelets promote the hematogenous metastasis process by arresting tumor cells within the organ vasculature (32,33). Meanwhile, tumor cells have the ability to aggregate platelets, leading to tumor cell-induced platelet aggregation that allows tumor cells to evade immune surveillance (34). It has been indicated that anti-platelet drugs, including heparin or warfarin, exert antitumor effects in vivo and in vitro (35). Clinical studies have shown that the risk of venous thrombosis in NSCLC patients is higher than that in tumor-free patients (36) and that high platelet count is correlated to a worse prognosis in NSCLC patients (37). In the present study, there was an association between the platelet count and DFS or OS time according to Kaplan-Meier analysis and log-rank test. The DFS and OS times were significantly longer in patients with a normal platelet count than in those with thrombocytosis. Usually, lymphatic metastasis is a strong prognostic factor for NSCLC. The present study showed that there was no association between the platelet count and survival whether the lymph node metastasis was present or not. Therefore, platelet count may not be a useful biomarker for predicting lymph node status.

There are several limitations to the present study, which should be taken into consideration. The study was retrospective and information on post-treatment recurrence was insufficient. However, the major positive factor of the study was the large population of NSCLC samples, which assisted in avoiding bias and offsetting the heterogeneity. A prospective study is also required to determine the prognostic value of MRP1 expression and platelet count.

In conclusion, MRP1 expression and platelet count are valuable independent prognostic biomarkers for survival in patients with operable NSCLC, and they should be assessed in patients with NSCLC in future studies to confirm their prognostic significance. Large prospective studies are required to validate these findings.

\section{Acknowledgements}

Not applicable.

\section{Funding}

The present study was supported by the Natural Science Foundation of Zhejiang Province (grant no. LY13H160028) and the Zhejiang Provincial Medicine and Health Science Fund (grant nos. 2013KYB048, 2015KYA035, 2017KY238 and 2017KY243).

\section{Availability of data and materials}

All data generated or analyzed during this study are included in this published article. 

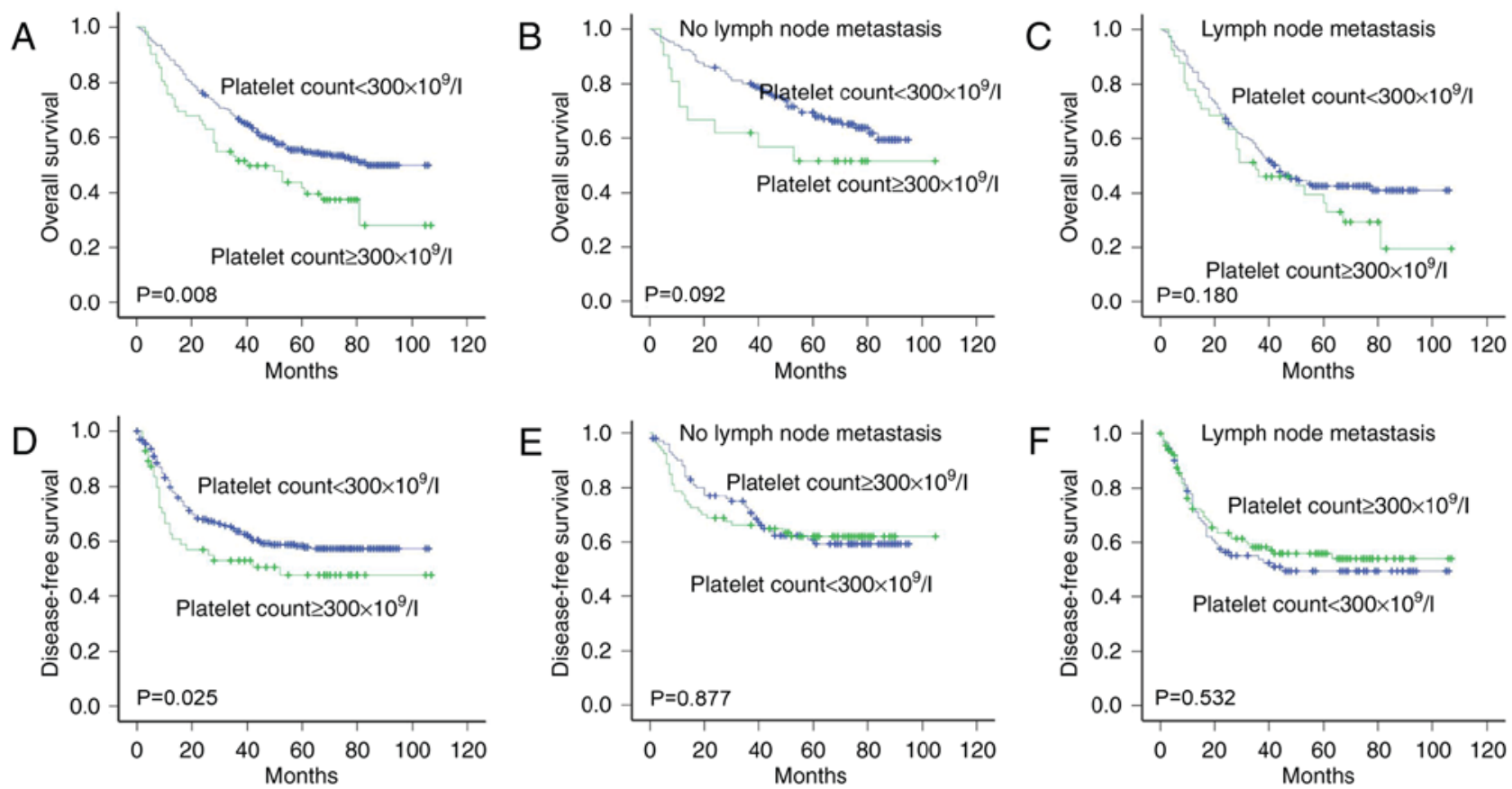

Figure 3. Kaplan-Meier OS and PFS curves according to MRP1 expression. (A) There was no association between MRP1 expression and OS (P=0.441). (B) In the patients with no lymph node metastasis, the OS was significantly longer in patients with positive MRP1 expression compared with those with negative expression ( $\mathrm{P}=0.009)$. (C) In the patients with lymph node metastasis, there was no association between MRP1 expression and OS. (D) There was no association between MRP1 expression and DFS ( $\mathrm{P}=0.656)$. (E) In the patients with no lymph node metastasis, there was no association between MRP1 expression and DFS. (F) In the patients with lymph node metastasis, the DFS was significantly shorter in patients with positive MRP1 expression than in those with negative expression ( $\mathrm{P}=0.022)$. MRP1, multidrug resistance-associated protein 1; OS, overall survival; DFS, disease-free survival.
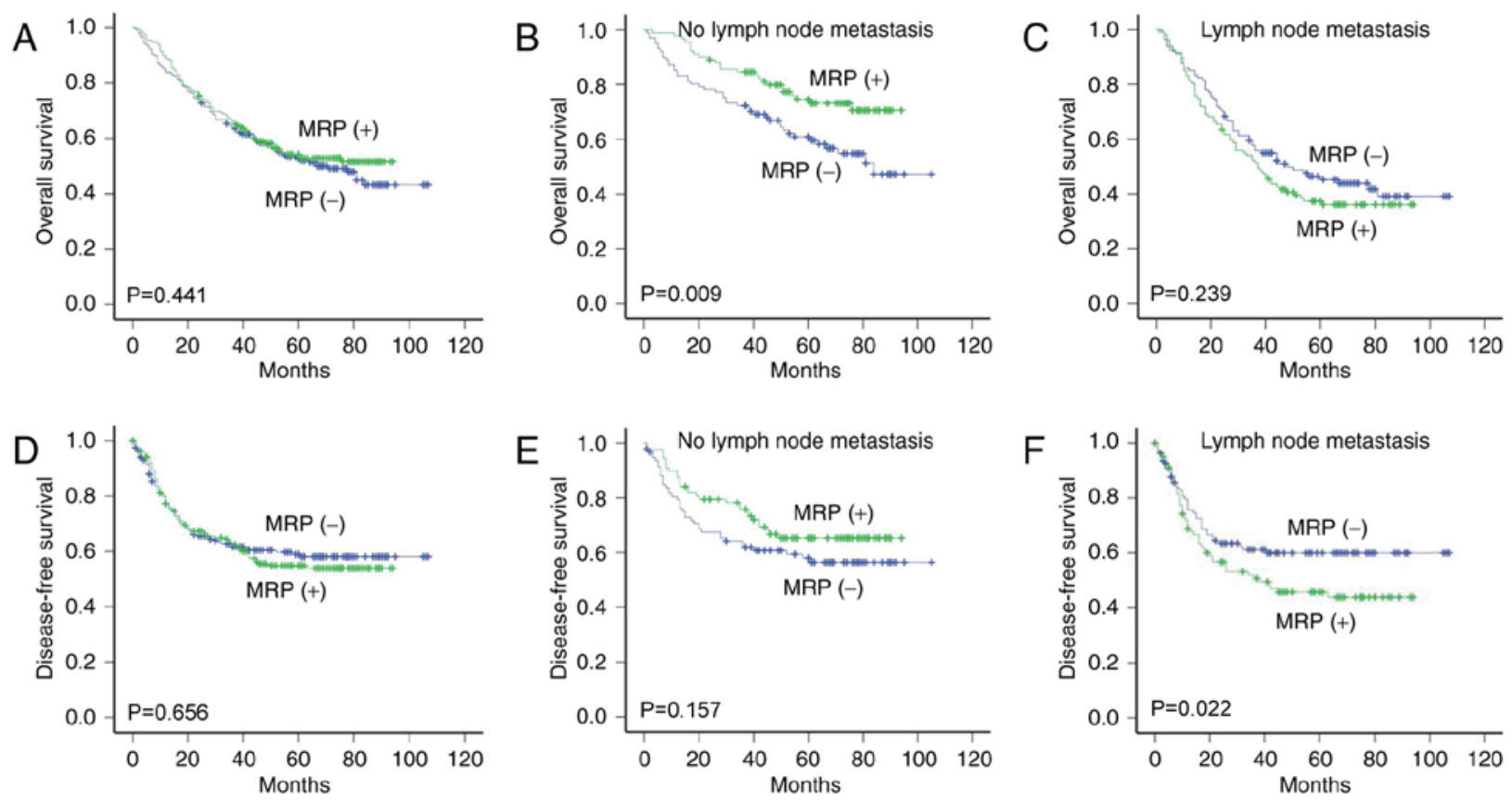

Figure 4. Kaplan-Meier DFS and OS curves according to platelet count. (A) The OS was significantly longer in patients with a normal platelet count $\left(<300 \times 10^{9} / 1\right)$ compared with in those with thrombocytosis $\left(>300 \times 10^{9} / 1\right)(\mathrm{P}=0.008)$. (B) There was no association between the platelet count and OS in the patients with no lymph node metastasis. (C) There was no association between the platelet count and OS in the lymph node metastasis patients. (D) The DFS was significantly longer in patients with a normal platelet count $\left(<300 \times 10^{9} / 1\right)$ compared with in those with thrombocytosis $\left(>300 \times 10^{9} / 1\right)(\mathrm{P}=0.025)$. (E) There was no association between the platelet count and PFS in the patients with no lymph node metastasis. (F) There was no association between the platelet count and PFS in the lymph node metastasis patients. OS, overall survival; DFS, disease-free survival.

\section{Authors' contributions}

JF contributed to study conception and design. LF, HS and
DW analyzed and interpreted patient data. CZ, RJ and XS performed the experiments and collected data. All authors read and approved the final manuscript. 


\section{Ethics approval and consent to participate}

All procedures involving human participants were approved by the Institutional Review Board of Zhejiang Cancer Hospital (Zhejiang, China). Informed written consent was obtained from all individual participants included in the present study.

\section{Consent for publication}

The patient provided written informed consent for the publication of any associated data and accompanying images.

\section{Competing interests}

The authors declare that they have no competing interests.

\section{References}

1. Siegel RL, Miller KD and Jemal A: Cancer statistics, 2017. CA Cancer J Clin 67: 7-30, 2017.

2. Hirsch FR, Varella-Garcia M, Bunn PA Jr, Di Maria MV, Veve R, Bremmes RM, Barón AE, Zeng C and Franklin WA: Epidermal growth factor receptor in non-small-cell lung carcinomas: Correlation between gene copy number and protein expression and impact on prognosis. J Clin Oncol 21: 3798-3807, 2003.

3. Reck M, Popat S, Reinmuth N, De Ruysscher D, Kerr KM and Peters S; ESMO Guidelines Working Group: Metastatic non-small-cell lung cancer (NSCLC): ESMO Clinical practice guidelines for diagnosis, treatment and follow-up. Ann Oncol 25 (Suppl 3): iii27-iii39, 2014.

4. Vallières E, Shepherd FA, Crowley J, Van Houtte P, Postmus PE, Carney D, Chansky K, Shaikh Z and Goldstraw P; International Association for the Study of Lung Cancer International Staging Committee and Participating Institutions: The IASLC Lung Cancer Staging Project: Proposals regarding the relevance of TNM in the pathologic staging of small cell lung cancer in the forthcoming (seventh) edition of the TNM classification for lung cancer. J Thorac 4 : 1049-1059, 2009.

5. Flens MJ, Zaman GJ, van der Valk P, Izquierdo MA, Schroeijers AB, Scheffer GL, van der Groep P, de Haas M, Meijer CJ and Scheper RJ: Tissue distribution of the multidrug resistance protein. Am J Pathol 148: 1237-1247, 1996.

6. Schinkel AH and Jonker JW: Mammalian drug efflux transporters of the ATP binding cassette (ABC) family: An overview. Adv Drug Deliv Rev 55: 3-29, 2003.

7. Cole SP: Targeting multidrug resistance protein 1 (MRP1, ABCC1): Past, present, and future. Ann Rev Pharmacol Toxicol 54: 95-117, 2014

8. Li A, Song J, Lai Q, Liu B, Wang H, Xu Y, Feng X, Sun X and Du Z: Hypermethylation of ATP-binding cassette B1 (ABCB1) multidrug resistance 1 (MDR1) is associated with cisplatin resistance in the A549 lung adenocarcinoma cell line. Int J Exp Pathol 97: 412-421, 2016.

9. Chen JJ, Liu SP, Zhao J, Wang SC, Liu TJ and Li X: Effects of a novel photoactivated photosensitizer on MDR 1 over-expressing human breast cancer cells. J Photochem Photobiol B Biol 171: 67-74, 2017.

10. Melguizo C, Prados J, Luque R, Ortiz R, Caba O, Alvarez PJ, Gonzalez B and Aranega A: Modulation of MDR1 and MRP3 gene expression in lung cancer cells after paclitaxel and carboplatin exposure. Int J Mol Sci 13: 16624-16635, 2012.

11. Luque R, Gonzalez Flores E, Delgado JR, Melguizo C, Prados JC, Gonzalez Astorga B, Ortiz R, Sánchez Toro C, Valdivia J and Aránega A: MDR1 gene expression in peripheral blood as a marker of treatment response in lung cancer. J Clin Oncol 30: 96, 2012.

12. Wu DD, Zhang JX, Li J and Dong WG: Lack of association of the MDR1 C3435T polymorphism with susceptibility to gastric cancer and peptic ulcer: A systemic review and meta-analysis. Asian Pac J Cancer Prev 15: 3021-3027, 2014.
13. Qiao W, Wang T, Zhang L, Tang Q, Wang D and Sun H: Association between single genetic polymorphisms of MDR1 gene and gastric cancer susceptibility in Chinese. Med Oncol 30 643, 2013.

14. Bambace NM and Holmes CE: The platelet contribution to cancer progression. J Thromb Haemost 9: 237-249, 2011.

15. Goubran HA, Stakiw J,Radosevic M and Burnouf T: Platelet-cancer interactions. Semin Thromb Hemost 40: 296-305, 2014.

16. Li FX, Wei LJ, Zhang H, Li SX and Liu JT: Significance of thrombocytosis in clinicopathologic characteristics and prognosis of gastric cancer. Asian Pac J Cancer Prev 15: 6511-6517, 2014.

17. Chadha AS, Kocak-Uzel E, Das P, Minsky BD, Delclos ME, Mahmood U, Guha S, Ahmad M, Varadhachary GR, Javle M, et al: Paraneoplastic thrombocytosis independently predicts poor prognosis in patients with locally advanced pancreatic cancer. Acta Oncol 54: 971-978, 2015.

18. Feng Z, Wen H, Bi R, Duan Y, Yang W and Wu X: Thrombocytosis and hyperfibrinogenemia are predictive factors of clinical outcomes in high-grade serous ovarian cancer patients. BMC Cancer 16: 43, 2016.

19. Josa V, Krzystanek M, Eklund AC, Salamon F, Zarand A, Szallasi Z and Baranyai Z: Relationship of postoperative thrombocytosis and survival of patients with colorectal cancer. Int J Surg 18: 1-6, 2015

20. Taucher S, Salat A, Gnant M, Kwasny W, Mlineritsch B, Menzel RC, Schmid M, Smola MG, Stierer M, Tausch C, et al: Impact of pretreatment thrombocytosis on survival in primary breast cancer. Thromb Haemost 89: 1098-1106, 2003.

21. Travis WD, Brambilla E, Noguchi M, Nicholson AG, Geisinger KR, Yatabe Y, Beer DG, Powell CA, Riely GJ, Van Schil PE, et al: International association for the study of lung cancer/american thoracic society/european respiratory society international multidisciplinary classification of lung adenocarcinoma. J Thorac Oncol 6: 244-285, 2011.

22. Berger W, Elbling L, Hauptmann E and Micksche M: Expression of the multidrug resistanceassociated protein (MRP) and chemoresistance of human non-small-cell lung cancer cells. Int J Cancer 1997: 73:84-93, 1997.

23. Young LC, Campling BG, Voskoglou-Nomikos T, Cole SP, Deeley RG and Gerlach JH: Expression of multidrug resistance protein-related genes in lung cancer: Correlation with drug response. Clin Cancer Res 5: 673-680, 1999.

24. Young LC, Campling BG, Cole SP, Deeley RG and Gerlach JH: Multidrug resistance proteins MRP3, MRP1, and MRP2 in lung cancer: Correlation of protein levels with drug response and messenger RNA levels. Clin Cancer Res 7: 1798-1804, 2001.

25. Ota E, Abe Y, Oshika Y, Ozeki Y, Iwasaki M, Inoue H, Yamazaki H, Ueyama Y, Takagi K, Ogata T, et al: Expression of the multidrug resistance-associated protein (MRP) gene in non-small-cell lung cancer. Br J Cancer 72: 550-554, 1995.

26. Oshika Y, Nakamura M, Tokunaga T, Fukushima Y, Abe Y, Ozeki Y, Yamazaki H, Tamaoki N and Ueyama Y: Multidrug resistance-associated protein and mutant $\mathrm{p} 53$ protein expression in non-small cell lung cancer. Mod Pathol 11: 1059-1063, 1998.

27. Berger W, Setinek U, Hollaus P, Zidek T, Steiner E, Elbling L, Cantonati H, Attems J, Gsur A and Micksche M: Multidrug resistance markers P-glycoprotein, multidrug resistance protein 1, and lung resistance protein in non-small cell lung cancer: Prognostic implications. J Cancer Res Clin Oncol 131: 355-363, 2005.

28. Yoh K, Ishii G, Yokose T, Minegishi Y, Tsuta K, Goto K, Nishiwaki Y, Kodama T, Suga M and Ochiai A: Breast cancer resistance protein impacts clinical outcome in platinum-based chemotherapy for advanced non-small cell lung cancer. Clin Cancer Res 10: 1691-1697, 2004

29. Filipits M, Haddad V, Schmid K, Huynh A, Dunant A, André F, Brambilla E, Stahel R, Pignon JP, Soria JC, et al: Multidrug resistance proteins do not predict benefit of adjuvant chemotherapy in patients with completely resected non-small cell lung cancer: International Adjuvant Lung Cancer Trial Biologic Program. Clin Cancer Res 13: 3892-3898, 2007.

30. Dvorak HF, Brown LF, Detmar M and Dvorak AM: Vascular permeability factor/vascular endothelial growth factor, microvascular hyperpermeability, and angiogenesis. Am J Pathol 146: 1029-1039, 1995

31. Ma L, Perini R, McKnight W, Dicay M, Klein A, Hollenberg MD and Wallace JL: Proteinase-activated receptors 1 and 4 counter-regulate endostatin and VEGF release from human platelets. Proc Natl Acad Sci USA 102: 216-220, 2005. 
32. Lewalle JM, Castronovo V, Goffinet G and Foidart JM: Malignant cell attachment to endothelium of ex vivo perfused human umbilical vein. Modulation by platelets, plasma and fibronectin. Thromb Res 62: 287-298, 1991.

33. Shim M, Song C, Park S, Choi SK, Cho YM, Kim CS and Ahn H: Prognostic significance of platelet-derived growth factor receptor- $\beta$ expression in localized clear cell renal cell carcinoma. J Cancer Res Clin Oncol 141: 2213-2220, 2015.

34. Jurasz P, Alonso-Escolano D and Radomski MW: Platelet-cancer interactions: Mechanisms and pharmacology of tumour cell-induced platelet aggregation. Br J Pharmacol 143: 819-826, 2004
35. Bobek V and Kovarík J: Antitumor and antimetastatic effect of warfarin and heparins. Biomed Pharmacother 58: 213-219, 2004.

36. Blom JW, Osanto S and Rosendaal FR: The risk of a venous thrombotic event in lung cancer patients: Higher risk for adenocarcinoma than squamous cell carcinoma. J Thromb Haemost 2: 1760-1765, 2004.

37. Barcala JG, Portal JA, Carmona MJ and González CM: Exposure to environmental contaminants and respiratory disease. Spotlight on the year 2009. Arch Bronconeumol 46 (Suppl 1): S17-S20, 2010 (In Spanish). 